\title{
P. Kulish's epistolary contacts (based on archival sources)
}

\author{
K. Timofieieva \\ Kyiv National University Culture and Arts, \\ Corresponding author. E-mail: voix@ ukr.net, ORCID: https://orcid.org/0000-0002-6996-0566
}

Paper received 30.07.21; Accepted for publication 22.08.21.

\begin{abstract}
https://doi.org/10.31174/SEND-Ph2021-257IX75-16
\end{abstract}
\begin{abstract}
The chosen topic is determined by an urgent necessity to look into Panteleimon Kulish's achievements as a piece of the Ukrainian society's history, especially in the field of humanities, with the archival science occupying an important place within. It is an important factor combining past, present and future through epistolary work. National revival in Ukrainian society is impossible without an objective reception of P. Kulish's creative heritage. At present, the letters of famous people are put at the level with other archival documents: protocols, notes, petitions, orders, diaries, and memoirs, notes of party and state bodies. Nowadays, in general use and open access there are huge archival collections, among which one can find many unprintable handwritten materials. Therefore, through a systemic and scrupulous scientific research, we are to find out the mysterious figure of P. Kulish, full of contradictions and contrasts, as state the scientists who have been studying his activities and work for more than a hundred years. However, the present stage of studying P. Kulish's activities raises a necessity of carrying out a more complete, deeper and more thorough development of documentary sources, including correspondence. The Kulish letters provide his researchers with reliable facts about the artist's biography and work, and allow them to study and analyze in detail the cultural space of that time, that is, one way or another, represented in today's reality, as history repeats itself. The modern researcher is attracted to P. Kulish's personality by the infinity of handwritten material, now awaiting its publication. With the involvement of archival material, the proposed publication considers various aspects of P. Kulish's relationship with his surroundings, analyzes his epistolary heritage as Kulish's correspondence is of a literary-scientific and cultural-social nature. Covering the views and ideas of P. Kulish, based on historical archival sources, the research addresses to documentary materials while working with epistolary sources, as well as introduces the writer's correspondence into scientific circulation.
\end{abstract}

Keywords: epistolary, P. Kulish, archival sources, documentary materials, manuscripts.

Introduction. Ukrainian society considers Panteleimon Kulish to be a prophet, mentor, preacher of the Ukrainian national idea, with the scientific community studying him as a writer, man of letters, critic, translator, ethnographer, publisher, publicist, historian, socio-political figure who tirelessly laid a solid foundation for development and the flourishing of Ukrainian literature and culture in general. The Ukrainian writer passed on his literary and scientific achievements to future generations, who continue to study his personality repeatedly, each time "discovering" P. Kulish both for themselves and for the world in a new way. After all, for the last two centuries P. Kulish has been an inexhaustible source, filling and nourishing Ukrainian national culture.

For many years his name was not only hushed up (his works were banned for the Ukrainian reader), but also misinterpreted, thus resulting in irreparable consequences for the perception of his descendants. Therefore, it is time to revive the invaluable forgotten treasures of not only Ukrainian literature, but also culture. P. Kulish left behind a large body of correspondence, which is a valuable scientific source and requires systematization and unification.

The disfigured notion of P. Kulish is caused by the Russian Empire censorship and policy, publishing his works in a "distorted" form. Thus, it will not be possible to truthfully read the story of his life through the prism of the epistolary, it will not be possible to achieve the truthfulness of his thoughts and views, he professed, until the censorship and writing of the applicant has been studied until our days. Moreover, we will not know the truth he has longed for all his life. However, it is well known that P. Kulish's life program consisted of educational activities for the people, the development of Ukrainian literature to strengthen and develop the Ukrainian nation, as well as the development of Ukrainian science (Miiakovskyi, 1928 , p. 43). The very statement that P. Kulish was the first European among Ukrainians and the first Ukrainian among the Europeans is based on "The Black Council" author to have professed pro-European ideas and principles of culture and society, and to have laid the first foundations for the emergence of Ukrainian culture in Europe (Slabchenko, 1909, p. 67). Not being able to freely and openly express his thoughts and views on national and politically public issues due to severe censorship, P. Kulish had to look for an audience in another way, mostly addressing to his personal acquaintances, using the tools of the epistolary.

P. Kulish's epistolary heritage is scattered in various archival institutions not only in Ukraine, but also abroad. These are the Department of Manuscripts of V.I. Vernadsky National Library of Ukraine of the National Academy of Sciences of Ukraine, the Department of Manuscripts and Textual Studies of Shevchenko Institute of Literature of the National Academy of Sciences of Ukraine, the Scientific Archival Funds of manuscripts and phonographs of the Rylsky Institute of Art Studies, Folklore and Ethnology of the National Academy of Sciences of Ukraine, the Central State Historical Archive of Ukraine, the Central State Archive-Museum of Literature and Art of Ukraine located in Kyiv; Chernihiv Regional Historical Museum named after V.V. Tarnovsky and Chernihiv Literary-Memorial Museum-Reserve of Kotsyubinsky in Chernihiv; the Central State Historical Archive of Ukraine, the Department of Manuscripts of Lviv National Scientific Library of Ukraine named after V. Stefanyk; and private collections, including the one of I. Eisenstock (I. Aizenshtok) based in Lviv; the Department of Manuscripts of the Russian National Library in St. Petersburg, the Department of Manuscripts of the Institute of Russian Literature of the Russian Academy of Sciences - The Pushkin House, Russian State Historical Archive in St. Petersburg; as well other institutions locat- 
ed in Moscow, Vienna, Prague and Warsaw and the Diaspora's archival materials. However, these are not all the places where P. Kulish's manuscripts have been preserved or are still preserved. This very fact convincingly proves the uniqueness of P. Kulish's figure and its significance for Ukrainian culture as a whole. The artist's new epistles introduced into scientific circulation will give us the opportunity to read his letters in a new way and analyze his literary, scientific, cultural and socio-political activities in the context of the Ukrainian society cultural and spiritual development, which is very relevant in our turbulent time.

Kulish's epistolary is a primary source for understanding the literary and socio-national processes of the XIX century, as evidenced by a number of correspondence (which is about three thousand letters) and the range of its recipients. Its correspondents were people of various social status, nationality and profession; among them were scientists, writers, publishers, censors, and there were prominent personalities who played an important role in the formation of national consciousness and the creation of Ukrainian history. Among them there are G. Galagan, both Tarnovsky - father and son, T. Shevchenko, O. and M. Bilozersky, M. Kostomarov, M. Grabowsky, D. Mordovtsev, I. Khilchevsky, D. Kamenetsky, S. Nos, N. Storozhenko, V. Barvinsky, M. Lobodovsky, M. Yuzefovich, M. Maksymovych, Y. Bodiansky, P. Chuikevych, A. Rambo, S. Aksakov, M. Drahomanov, M. Pavlyk, Marko Vovchok, M. Nomys (Symonov), Kulish's wife O. Bilozerska-Kulish (Hanna Barvinok), P. Pletnov, O. Konysky, L. Myloradovychivna, I. Puliui, P. Serdiuk, Yu. Krashevsky and many others. We can name up to a hundred names of people whom P. Kulish corresponded with, and they were all bright and diverse figures, or people close in spirit. Apparently, no Ukrainian writer has left behind such a huge epistolary heritage as P. Kulish.

Until now, some letters of P. Kulish remain unpublished. These are the letters to his wife, her brothers Bilozersky (Mykola, Oleksandr, Ivan, Olimpii, Viktor), and his mother; the letters to P. Pletnov, M. Makarov, O. Makarova, O. Smyrna, M. Herbel, P. Chuikevych, I. Slavnytsky; some letters to Y. Bodiansky and V. Shenrok; letters of the 1890 s, grouped in a black notebook by P. Kulish, many letters to unidentified addressees, and others. Kulish's letters, published immediately after his death, when it was impossible to print untrimmed texts that concerned people who were still alive, require clarification and additions. Significant reductions were made during the publication of the writer's letters to O. Kistiakivsky (Ukrainian criminal scientist, lawyer and public figure).

Other letters of P. Kulish turned out to be even in a worse state. Most of them were destroyed in a fire at the Motronivka khutir (farm) in 1885. However, even the correspondence that was saved remains unpublished among them are letters from M. Drahomanov, M. Pavlyk, N. Kobrynska, K. Trylovsky, O. Konysky, P. Pletnov, A. Metlynsky, etc.

The modern stage of the scientific study of P. Kulish's works began with the 35 volume publication of the "Complete Works of Kulish" edited by George G. Grabowicz. According to him, the significance of Kulish's personality in the history of Ukrainian culture was considered as a central, key figure in the formation of modern Ukrainian literature and culture, and at the same time Panteleimon Kulish was the mover and the founder of the newest Ukrainian intellectual, critical thought and those dimensions of the national consciousness that rely on it (Kulish, 2005, p. 7). Last year (2019) Shevchenko Institute of Literature of the National Academy of Sciences of Ukraine announced a 40-volume edition of the writer's works and letters. Today, Kulish's works are returning to scientific circulation, overcoming material difficulties in this process. But a long-lasting (more than half a century) period of Panteleimon Kulish name oblivion preceded these events. The scientific study of his work was suspended and prohibited under the "bourgeois nationalist" heading. It was possible to conduct scientific activities only abroad, but the researchers did not have access to the archival institutions where the documents and materials of Kulish's day were kept.

The circle of modern scientists, studying this issue, involves representatives of various humanities, with some of them been developed by P. Kulish to a great extent, and in which he discovered himself. Among these representatives are O. Fedoruk and his work "Panteleimon Kulish. Complete collection of works. In 2 Volumes. Letters", Ye. Nakhlik and O. Nakhlika's work "Panteleimon Kulish: between Paraskeva Hlibova and Horpyna Nikolaieva", N. Krutikova's "Letters of P. Kulish to V. Shenrok", S. Zakharkin "Letters of P. Kulish to Ye. Tymchenko", Zh. Liakhov's "Mykola Gogol's Epistolary as an Artistic Self-Disclosure of Personality in P. Kulish's Research", N. Pobirchenko's “Life and figure of Panteleimon Kulish in Correspondence, Memoirs of His Contemporaries and Admirers", V. Pustovit's "Ukrainian Literary Epistolary of the XIX Century: depicting the literary process development", O. Kravchenko's "Panteleimon Kulish. Life Devoted to the Enlightenment", O. Yaskiv's "Historical Views of Panteleimon Kulish in the Light of Intellectual Metamorphoses in 1870-1880s". Despite the extensive processing of the indicated issue, there are still many gaps in the identification and scientific study of P. Kulish's epistolary work.

The purpose of the article is scientifically to reconstruct the epistolary heritage of Panteleimon Kulish, which is in the archives of Ukraine. Nowadays, the writer's archival materials are returning to scientific use, which is very relevant for Ukrainian society. Continuing the work of Kulish scholars, we aim to highlight and analyze the achievements of P. Kulish, which directly influenced both the formation and the current state of a progressive, nationally shaped Ukrainian society.

The research methodology is based, primarily, on the methods of archival and source studies, as well as on biographical analysis (for reconstruction of life and creative path), on historical analysis (for reproduction of chronological boundaries in which correspondence between addressees took place), culturally historical method (aimed at highlighting the main views and ideas of P. Kulish, based on historical archival sources, and influenced the modern Ukrainian nation formation).

Presenting main material. The outstanding artist's personality occupies a unique place in the Ukrainian public life of the XIX century. According to English historian 
David Saunders, P. Kulish was one of the key figures of the Ukrainian historical period of the past (Saunders, 1985). M. Drahomanov aptly said that Kulish was one of the Ukrainophiles, who hit the point of the world, human culture, which would raise the Ukrainian people (Mohylianskyi, 1925, p. 180). V. Shchurat (1897, p. 37) called Kulish the patriarch of Ukrainian literature. M. Gogol, whose letters Kulish studied, wrote about his future researcher that he (Kulish) would occupy an important place in our literature (Perepiska ..., 1998, p. 258). Our contemporary academician M. Zhulynskyi emphasizes that Kulish sought to create a new spiritual and psychological atmosphere in Ukrainian society, which catastrophically lost the moral and spiritual foundations of social life under the aggressive pressure of the Russian autocracy (Zhulynskyi, 2000, p. 8). The definition given by M. Globenko that our citizens still do not know Kulish is very indicative for our social and political reality [Hlobenko, 1961, p. 316].

The epistolary image of a creative person is usually more complex and dimensional than the one emerging from his works and general biographical information (Kotsiubynska, 2002, p. 117). From the writer's correspondence, there emerges a self-portrait of the artist of the word, his spiritual image, firstly applying to P. Kulish by himself. His letters provide his researchers with reliable facts about the biography and creative work of the writer. In addition, we should note that the volume of his correspondence is impressive.

V. Pustovit notes that P. Kulish left a large and meaningful memoir heritage, which provides a lot of interesting material for understanding the figure of the artist and the historical environment in which the writer lived and worked (Pustovit, 2019).

According to O. Fedoruk, Kulish's letters in general are a kind of novel in letters, a novel-chronicle, compositionally unsurpassed, mosaic, like life itself, and most importantly - true and quite psychological. In this sense, the letters are a self-sufficient genre, with the protagonist of which being a "hot Kulish" (Fedoruk, 2000, p. 7).

Correspondence sent to P. Kulish to the Motronivka khutir (farm) was carefully kept in a box, which, according to the writer's wife O. Bilozerska-Kulish (Hanna Barvinok - her literary pseudonym), was completely filled with interesting letters (Shuhurov, 1899, p. 17). O. Fedoruk notes that P. Kulish was extremely responsible and careful as to epistolary dialogues. He rarely hesitated to answer and the correspondence intensity often depended on the addressee himself. Quite often P. Kulish sent letters one after another, perhaps, with the aim of not exchanging news or thoughts as much as just talking. Therefore, he repeatedly complained about his correspondents because of their careless attitude to correspondence (Fedoruk, 2000, p. 29). Thus, it is no coincidence that in a friendly letter (dated July 23, 1866) to I. Khilchevsky from Warsaw, P. Kulish remarked: Write to me often and thoroughly (Pis'ma P. Kulisha $\mathrm{k}$ I. F. Khil'chevskomu, 1898, p. 86), in such a way encouraging his addressees to epistolary punctuality. Moreover, P. Kulish was tireless in his daily intellectual work and could not understand the irresponsibility and inaccuracy of his correspondents. In confirmation of his ability to work, in one of his letters to I. Khilchevsky (dated June
30, 1869), P. Kulish wrote: I work constantly - this is my normal state of existence. Otherwise, I would be lost from boredom. There is no god but Allah, and Muhammad is his prophet. There is no life outside of work, and I am a lover of work. I will stop working on the day of my death, even if it is actually to happen in 25 years. There are many harvesters, but few of doers. My studies support me, but not exhaust me: believe it (Pis'ma P. Kulisha $\mathrm{k}$ I. F. Khil'chevskomu, 1898, p. 96).

During his lifetime, P. Kulish deposited his manuscript translations of the Bible in the V. Tarnovsky Museum, writing a letter (dated October 4, 1886) to its owner: Meanwhile, I decided to hide my handwritten works for my heirs (and there will be more than one or two, I hope) in your museum. Our word is immortal. Let them see how their ancestor worked, and they work the same way (Shuhurov, 1899, p. 12). After P. Kulish's death, according to his will, Hanna Barvinok passed other manuscripts to V. Tarnovsky. Also, the handwritten materials of Kulish ended up in Y. Bodiansky, P. Doroshenko, N. Shakhovsky, in turn, M. Tymchenko kept the manuscripts of Shakespeare's translations, however, they were then returned to the author, although it is not known either in full and/or without changes. As for the epistolary heritage of P. Kulish, after his death, some autograph letters and copies of the letters (made by his wife) were given to V. Shenrok for writing a writer's biography, in particular these were the letters from V. Tarnovsky, O. Khanenko, D. Kamenetsky. Thus, it is clear why so much Kulish's materials have been scattered across various archives and funds, with some of them not been found at all yet.

O. Barvinsky, a public and political figure, was also among P. Kulish's addressees. He worked on the creation of "Chytanka" (a book for reading) for high school students, which should provide examples of oral folk art and some works of the Ukrainian writers of the XIX century. Since O. Barvinsky did not have enough experience and information about the Ukrainian literary figures to conclude such a book for reading, therefore, through a letter to M. Lysenko, he distantly met P. Kulish, who gladly provided the necessary information for such scientific research. Later, O. Barvinsky directly addressed P. Kulish as to an expert who knew who had developed and who had not developed the Ukrainian word (Barvinsky, 1912, p. 191). Their friendly relations and written communication were engraved in O. Barvinsky's memoirs. Recalling about P. Kulish, he wrote that he had been allowed to look deep into his sincere patriotic soul, to know Kulish's character well. That despite all hesitations and mistakes O. Barvinsky had not ceased to appreciate P. Kulish as a very noble man, a multifaceted and well-deserved figure, being prominent for our national, literary and cultural development (Barvinsky, 1912, p. 15).

As a true intellectual and encyclopaedist, P. Kulish had a good sense of humour, illustrated in his letter to I. Puliui in the summer of 1880. Paying attention to the respectable age of the addressee, the writer drew attention to the fact that intellectual work prolongs age and promotes longevity. He wrote: You see, my dear friend, that reading books is harmless as to my health: I have been doing it for forty years, but I do not have health effects yet, and those people who walked at parties and avoided hard work, have long ago moved to the realm of the dead (Puliui, 1905, p. 
$51)$.

The preface to the special issue of the "Knyhar" (Scribe/ Scholar) magazine (1919), devoted to the 100th anniversary of P. Kulish's birth, eloquently stated that only then, on his birth centenary, it became the time of P. Kulish objective scientific study. P. Kulish became for us not a living opponent, but an interesting and instructive page of the past, a necessary stage in the history of our cultural development - and at the same time a faithful servant of the Ukrainian word, who despite all his mistakes and solemn promises, had not renounced "his Ukrainian pen" (Zaitsev, 1919, p. 49). Over the next hundred years, there were many transformations in the study of both the figure and the work of the writer. In the 1920s there was published a large array of Kulish's epistolary works, marking the beginning of scientific studies on Kulish's epistolary texts. The 1920 s and 1930 s proved to be very fruitful for scientific researches that influenced the Kulish studies formation, which included the spheres of literary studies, philology, philosophy, cultural studies, history and historiography of Ukraine, pedagogy and political science. It was considered to be the flourishing period of the Kulish's heritage study.

The proclamation of Ukraine's independence only contributed to and influenced the historical course of events. There began the process of returning the P. Kulish's figure to the post-Soviet cultural space of Ukraine. The writer's creative heritage returned to the scientific circulation, with his unpublished texts been introduced and his forgotten works actualized. Researchers mastered the work of predecessors, but, through the generation, this process took place somewhat spontaneously and unsystematically; there were set new tasks within the study of P. Kulish's biography, work, and his worldview, in a broader context, it was the study of his environment. The introduction of P. Kulish's works in the programs of secondary and higher educational institutions and the rapid development of university science additionally stimulated further researches, unfortunately with many of them having no scientific value. This is evidenced by the materials of the interuniversity scientific conference in Sumy region (1994), which was dedicated to the 175th anniversary of P. Kulish birth. Based on the results of the conference, there was a publication, consisting of a preface and 15 scientific articles and reflecting the Kulish studies development state of those days, which after many years of oblivion and the Soviet worldview pressure continued the established tradition. However, the reports' topics were mainly literary, not without the notorious comparison of P. Kulish and T. Shevchenko, but there was no research devoted to archival materials, such as manuscripts, letters, diaries, memoirs.

The year 2019 was an anniversary one for Kulish scholars - the 200th anniversary of the writer's birth. Many scientific studies were devoted to this event, with several collections of abstracts been published as resulting from the scientific conferences held in Lviv, Sumy, Kyiv and other cities.

The Ukrainian society has not yet properly appreciated the scientific and creative heritage, culturally educational and socially political activity of P. Kulish, which makes a significant contribution to the cultural and intellectual space of Ukraine. Today he is more relevant than ever, as the issues of language, religion and political orientation remain unresolved and speculative. After all, a society change is possible due to its consciousness change. In addition, as P. Kulish notes in his "Zhyzn Kulisha" (Kulish's Life), the basis of those changes, set by the Holy Scriptures, is heart's purity, righteous education, freedom for the ordinary people, and a Christian self-sacrifice (Kulish, 2005, p. 128).

The cultural component of any society is education, language, art, which are the main factors, significantly influencing human consciousness and awareness. Thus, P. Kulish, armed with these basic attributes, affected the formation of Ukrainian national consciousness, which was the main idea of his life. This issue remains unresolved both in Ukrainian society and at the state and legal level.

Therefore, the cultural activity of Panteleimon Oleksandrovych was inseparable from his political and social affairs, as culture and politics are an integral part and a guarantee of the socio-economic well-being of society. P. Kulish understood that the social well-being of the people depends on the level of its cultural development, as he said: We knew that neither a law nor a decree abolished serfdom in England, but it was the culture that destroyed it (Pobirchenko, 2010, p. 80).

The writer tried to engage the Ukrainian reader in European literature, using the Ukrainian translations of Shakespeare, Byron, Goethe, Heine, and Schiller's works. He made great efforts to ensure that the native language had the necessary resources and tools to reproduce the foreign word beauty in the Ukrainian translation. P. Kulish did many valuable and useful things in this direction. In his correspondence (August 26, 1881) with O. Barvinsky, P. Kulish admitted: If Shakespeare works became a favourite reading, they would sober up our meagre literature and give it wings. Moreover, if Shakespeare's comedies and tragedies brought our fellow citizens to the theatre, it would be a better school for them than all our writing and singing. This is my goal; this is my motivation for translating Shakespeare's works (Barvinsky, 1912, p. 189). P. Kulish was indescribably happy and proud when Ukrainian-language texts were translated into European languages. In one of his letters (February 6, $1845)$ to O. Khanenko the writer notes: You will no doubt be curious to know that our folk songs are translated into French and German. The manuscript of the French translation passed through my hands, and I could not help but admire our native poetry in the common European language: it is in a new splendour and freshness. The edition will be published in Paris (Sheveliv, 1928, p. 150).

Thanks to P. Kulish and I. Puliui, the Ukrainian people can read and study the Bible in their native language. It brings our Ukrainian nation closer, unites and consolidates it. The Bible is that living centre that for centuries has been carrying encoded information for humankind. P. Kulish shares his thoughts about the Holy Scriptures with M. Gattsuk in his letter dated September 4, 1872: Not religion, but literature is in my mind. Our word will have some use from my translation... It may be that someday religion will disappear, as there disappears the trace of our lives, but when relied on reasonable, true exegesis, it will take its share of use from my work (Savchenko, 1929, p. 49). 
The author of "The Black Council" was rightly recognized as a competent Ukrainian historian, public and political figure. Along with such prominent personalities as M. Maksimovich, M. Kostomarov, O. Levitsky, M. Ivanyshev, M. Vladimirsky-Budanov, V. Antonovych etc., P. Kulish was at the origins of Ukrainian archival science. Engaged in archival activities, he aimed to cover important moments of the past of Ukraine in a publicly accessible form and to accustom the broad masses to a conscious attitude and understanding of native antiquity (Hrushevsky, 1914, p. 26). Uniting both scientistsspecialists and amateurs, Kyiv Archaeographic Commission contributed to the education of qualified historians, archaeologists, archivists in Ukraine. Its members were of different social status and political views, which undoubtedly affected the activities of the institution. Over there, T. Shevchenko worked from December 1845 to March 1847, P. Kulish carried out his archeographic expeditions, M. Kostomarov worked on Cossack chronicles, M. Gulak rewrote historical documents. The scientific engagement in the Commission's work influenced not only the work and life of each of them, but, in general, affected the activities of the Cyril and Methodius Society, as well reflecting in the form and content of its program documents (Zhurba, 1993).

P. Kulish was a member of Kyiv Archaeographic Commission, which searched for and collected sources of Ukrainian history for scientific processing. In essence, the archive is a carrier of objective information, the original source, so P. Kulish, looking for historical truth, wanted to restore historical events by searching for folk memories and legends. To confirm our opinion, we have a P. Kulish's letter (January 1, 1856) to S. Aksakov: At the same time, God sees how I thirst for the truth, at least with the sacrifice of my most precious beliefs (Hudzii, 1957, p. 68). The writer wanted to involve the Ukrainian community in truthful Ukrainian history, so that the Ukrainian people were aware of historical sources, could think critically, using true materials. According to V. Petrov (1928), it happened historically and ironically that researching archival heritage, P. Kulish himself became an archival writer, because many of his works have still been stored in archival institutions not only in Ukraine but also abroad.

P. Kulish pinned great hopes on the future generation, which would appreciate the achievements of their predecessors, and believed in future readers and objective critics. First, as the writer believed, they should be brought up on the best examples of Ukrainian literature. The writer said: I will soothe my soul only with future generations, following to self-knowledge and self-activity in their na- tive land... (Knyhar, 1919). In a letter (November 28, 1892) addressed to M. Pavlyk, the writer noted: I wish a good deed would be done: someone would collect my letters not for the sake of my "I", but for what is written (Vozniak, 1928, p. 176).

Conclusions. Studying the epistolary heritage of P. Kulish, we have concluded that his letters are a living chronicle of our cultural and national life, covering a half of a century period - from 1840's to 1890 's. P. Kulish was and remains incompletely discovered and read phenomenon of the XIX century. We only have to find new facts, phenomena, events that in one way or another had an impact on his formation as a person and as the main driver of the national idea. Due to his persistent and tireless publishing, journalistic, translation, literary-critical, literary, pedagogical, historical-ethnographic work as well as socially political and educational activities P. Kulish is the foundation of the Ukrainian national consciousness and statehood, which Ukrainians have always lacked, especially nowadays. By creating the Kulishivka and translating the Bible, the writer united and consolidated Ukrainian society. What we, as a nation, are today, we owe to him. Studying, analyzing the artist's biography and work through the prism of modern realities, and summarizing, we note that P. Kulish encouraged Ukrainians to selfawareness as a separate spiritual community. It should be noted that the scope of P. Kulish's epistolary heritage is not inferior to the writing array of any Ukrainian artist or public and political figure of Ukraine in its factual and various style. Thus, it is time to systematically publish and study the scattered Kulish's materials. Only in this way, we will be able to destroy the existing tendentiousness, as well as break the web of myths and legends that shrouded his figure.

However, despite such a multifaceted activity of P. Kulish and his achievements in the Ukrainian humanities, our society is still prejudiced against such an outstanding and extraordinary personality. There are several reasons of this: the Soviet ideology, still prevailing in the minds of many Ukrainian citizens, the low level of education and spirituality, the lack of the Ukrainian culture popularization. Despite various social and economic barriers, the name of Panteleimon Kulish is under revival. It is evidenced by numerous events, dedicated to the artist's work and activities, as well publishing of his works and scientific collections, holding scientific conferences and round tables with not only Ukrainian but also foreign scientists and scientific institutions. His literary and intellectual achievements give us the opportunity to read and analyze the history of Ukrainian culture, which is very relevant for today's Ukrainian society.

\section{REFERENCES}

1. Barvinskyi, O. (1912). Spomyn z moho zhyttia [A memory from my life]. Lviv, [in Ukrainian].

2. Hlobenko, M. (1961). Z literaturnoi spadshchyny [From the literary heritage]. Paris: Nationalist Publishing House in Europe. 114-132.

3. Hrushevskyi, O. (1914). Shevchenko i Kulish [Shevchenko and Kulish]. Shevchenkivskyi zbirnyk, 1, 17-23 [in Russian].

4. Hudzii, M. (1957). Nevidomi lysty P. O. Kulisha do Aksakovykh [Unknown letters of Kulish to Aksakov]. Radianske literaturoznavstvo, 19, 56-120 [in Ukrainian].

5. Zhurba, O. (1993). Kyivska arkheohrafichna komisiia 1843-

1921. Narys istorii i diialnosti [Kyiv Archeographic Commission 1843-1921. Essay on history and activity]. Kyiv: Naukova Dumka [in Ukrainian].

6. Zhulynskyi, M. (2000). Rozumity vysoke znachennia liudyny: kulturnytstvo P. Kulisha yak vidpovid na vyklyky epokhy [Understand the high value of man: the culture of P. Kulish in response to the challenges of the era]. Panteleimon Kulish: Materialy i doslidzhennia.Lviv-New York-Kyiv: MP Kotz [in Ukrainian].

7. Zaitsev, P. (1919). Vydannia tvoriv Kulisha [Publication of works by Kulish]. Knyhar, 23-24, 48-56 [in Ukrainian]. 
8. Iv. K-Y. (1924). Do zhyttiepysu Kulisha. Na prykladi lystiv z P. Hlibovoiu [To Kulish's biography. On the example of letters with P. Glibova]. Chervonyi shliakh, 8-9, 268-285 [in Ukrainian].

9. Kyryliuk, Ye. (1929). Panteleimon Kulish [Panteleimon Kulish]. Kharkiv-Kyiv [in Ukrainian].

10. Knyhar (1919). Litopys ukrainskoho pysmenstva [Chronicle of Ukrainian Writing]. Kyiv: „Tchas” Society [in Ukrainian].

11. Korniienko, V. (2000). Panteleimon Kulish i KyryloMefodiivske bratstvo [Panteleimon Kulish and the Cyril and Methodius Brotherhood]. Tvorchi ta ideini shukannia P. O. Kulisha v konteksti sohodennia : zb. nauk. pr., 173-175 [in Ukrainian].

12. Kulish, P. (2005). Povist pro ukrainskyi narod; Moie zhyttia (Zhyzn Kulisha) [The story of the Ukrainian people; My Life (Kulish's Life)]. Kyiv: Ukrainskyi Svit [in Ukrainian].

13. Kulish, P. (2005). Povne zibrannia tvoriv. U 2. t. T. 1: Lysty [Complete works. In Volume 2. Volume 1: Letters]. Kyiv: Krytyka [in Ukrainian].

14. Kulish, P. (1993). Shchodennyk [Diary]. Kyiv [in Ukrainian].

15. Kotsiubynska, M. (2001). Zafiksovane i netlinne: rozdumy pro epistoliarnu tvorchist [Fixed and incorruptible: reflections on epistolary creativity]. Kyiv: Spirit and Letter; Kharkiv: Human rights group [in Ukrainian].

16. Materialy mizhvuzivskoi naukovoi konferentsii Sumshchyny, prysviacheni 175-ty richchiu $\mathrm{z}$ dnia narodzhennia P. O. Kulisha (1994). [Proceedings of the Sumy Region Inter-University Scientific Conference on the 175th Birth Anniversary of P. Kulish]. Sumy [in Ukrainian].

17. Miiakovskyi, V. (1928). Liudy sorokovykh rokiv (Kyrylomefodiivtsi v yikh lystuvannia) [People in their forties (Cyril and Methodius in their correspondence)]. Za sto lit, 2, 33-98 [in Ukrainian].

18. Mohylianskyi, M. (1925). P. O. Kulish u 90 rokakh (Lysty y dokumenty) [P. Kulish in 90 years (Letters and documents)] Chervonyi shliakh [in Ukrainian].

19. Naumov, E. (1987). Chastnaya perepiska XIX - nachala XX v., kak ob"ekt arkheograficheskogo analiza [Private correspondence of the 19th - early 20th centuries as an object of archaeographic analysis]. Arkheograficheskii ezhegodnik za 1986. Moscow[in Russian].

20. Panteleimon Kulish: pysmennyk, filosof, hromadianyn (Do 190-richchia vid dnia narodzhennia P. O. Kulisha), (2009) [Panteleimon Kulish: a writer, a philosopher, a giant (Until 190-richchya on the day of the birth of P. Kulish)]. Khronika-2000, 78. Kyiv [in Ukrainian].

21. Perepiska N. V. Gogolya (1998) [Correspondence of N.V. Gogol] U 2 t. t. 2. Moscow [in Russian].

22. Petrov, V. (1928). Panteleimon Kulish u piatdesiati roky. Zhyttia. Ideolohiia. Tvorchist [Panteleimon Kulish in the fifties. Life. Ideology. Art]. Kyiv: All-Ukrainian Academy od Science Publishing [in Ukrainian].

23. Pis'ma P. Kulisha k I. F. Khil'chevskomu (1898) [Letters from P. Kulish to I. Hilchevsky]. Kievskaya starina, 60, №13, 84-149 [in Ukrainian].

24. Pobirchenko, N. (2010). Zhyttia i postat Panteleimona Kulisha u lystuvanni, spohadakh suchasnykiv ta shanuvalnykiv [The life and figure of Panteleimon Kulish in correspondence, memoirs of contemporaries and admirers]. Uman: PE Zhovtyi O. O. [in Ukrainian].

25. Pustovit, V. (2019). Ukrainskyi pysmennytskyi epistoliarii XIX st. : vidobrazhennia perebihu literaturnoho protsesu [Ukrainian Writing Epistolary of the 19 th Century : Reflects the progress of the literary process] [Monograph]. Kharkiv: Ivanchenko I. S. Publishing House [in Ukrainian].

26. Puliui, I. (1905). Novi i pereminni zvizdy [New and variable stars]. Vienna [in Ukrainian].

27. Savchenko, F. (1929). Spivrobitnytstvo P. Kulisha z O. Hattsukom [Collaboration of P. Kulish with O. Gatsuk.] Zbirnyk filolohichnoi sektsii Naukovoho tovarystva imeni Shevchenka, 1, 43-72 Lviv [in Ukrainian].

28. Slabchenko, M. (1919). Do istorii vidnoshen mizh P. Kulishem ta T. Shevchenkom [On the history of relations between P. Kulish and T. Shevchenko]. Sbornik Khar'kovskogo istoriko-filologicheskogo obshchestva, 18, 345358 [in Ukrainian].

29. Stebnytskyi, P. (1919). Kulturno-hromadska pratsia P. O. Kulisha [Cultural and social work of P. Kulish]. Knyhar [in Ukrainian].

30. Studynskyi, K. (1903). Z lystiv P. Kulisha do Omeliana Partytskoho [From P. Kulish's letters to Omelyan Partytsky]. Lviv [in Ukrainian].

31. Sumtsov, M. (1919). Panteleimon Kulish [Panteleimon Kulish]. Poltava: Publication of the Native Word newspaper [in Ukrainian].

32. Fedoruk, O. (1997). P. Kulish. Lysty do M. D. Bilozerskoho [P. Kulish. Lysty do M.D. Bilozers'koho]. Lviv-Niu-YorkKyiv: M. P. Kots [in Ukrainian].

33. Sheveliv, B. (1928). Storinky z zhyttia P. Kulisha za 40-kh rr. (Lysty P. Kulisha do O. Khanenka [P. Kulish's life pages in the 1940s (Letters from P. Kulish to O. Hanenko)]Zhyttia i revoliutsiia, 10, 150-151 [in Ukrainian].

34. Shuhurov, N. (1899). U mohyl P. A. Kulysha y V. M. Błlazerskoho [At the graves of P. Kulish and V. Belazersky]. Ottisk iz zhurnala «Kievskaya Starina» [in Ukrainian].

35. Shchurat, V. (1897). Do ostannoho pobutu P. Kulisha u Lvovi Kulisha [Until the last life of P. Kulish in Lviv]. Lviv [in Ukrainian].

36. Saunders, D. (1985). The Ukrainian Impact on Russian Culture 1750-1850. Edmonton [in English].

37. Vozniak, M. (1928). Ostanni znosyny P. Kulisha Z halychanamy: ( $\mathrm{Z}$ dodatkom yoho lystuvannia $\mathrm{Z} \quad \mathrm{M}$. Pavlykom) [P. Kulish's recent relations with the Galicians: (With the addition of his correspondence with M. Pavlik)]. Zapysky Naukovoho tovarystva imeni Shevchenka. Pratsi istorychno-filolohichnoi sektsii, 148, 165-240. Lviv, [in Ukrainian]. 